\title{
Enumeration of fermentative and hydrolytic micro-organisms from three sanitary landfills
}

\author{
A. C. Palmisano, ${ }^{*}$ D. A. MarusciK and B. S. Schwab \\ Environmental Safety Department, The Procter \& Gamble Co., Ivorydale Technical Center, Cincinnati, \\ OH 45217, USA
}

(Received 14 April 1992; revised 7 September 1992; accepted 21 October 1992)

\begin{abstract}
Fermentative bacteria were isolated from refuse excavated from municipal solid waste landfills in New York, Florida and Arizona. Anaerobic bacteria cultured on enriched solid media ranged from $10^{5}$ to $10^{8}$ c.f.u. ( $g$ dry wt of refuse $)^{-1}$. A significant correlation $(P<0.03)$ was found between numbers of anaerobes cultured at $37^{\circ} \mathrm{C}$ and moisture content of refuse. Bacteria hydrolysing starch and protein represented 0-15\% of the total anaerobes cultured; no anaerobic bacteria hydrolysing ball-milled cellulose were isolated. Aerobic bacteria isolated on enriched medium ranged between $10^{4}$ and $10^{7}$ c.f.u. $(\mathrm{g} \mathrm{dry} \mathrm{wt})^{-1}$. Direct microscopic counts of total bacteria associated with refuse were in the order of $10^{10}$ bacteria $(\mathrm{g} \mathrm{dry} \mathrm{wt})^{-1}$. These data suggest that, despite relatively high densities of bacteria in landfills, polymer hydrolysis is mediated by a small percentage of the fermentative population.
\end{abstract}

\section{Introduction}

Public concern with the disposal of municipal solid waste (MSW) in landfills has escalated in recent years as existing landfills close and new landfills become difficult to site (Carra \& Cossu, 1990). In the US, an estimated $73 \%$ of MSW (118 million metric tons) was landfilled in 1988 (USEPA, 1990). Materials generated in the MSW stream in the US were of approximately $40 \%$ paper and paperboard, $17.6 \%$ yard waste, $7 \%$ glass, $8.5 \%$ metals, $7.4 \%$ food wastes, $8 \%$ plastics, and $11.6 \%$ other refuse, by weight (USEPA, 1990).

Components of the organic fraction of refuse may serve as substrates for micro-organisms in landfill environments (Grainger et al., 1984; Archer \& Robertson, 1986; Sleat et al., 1987). The chemical composition of refuse includes polymers such as cellulose, starch, protein and lignin (Jones \& Grainger, 1983). Aerobic bacteria may have a minor role in refuse decomposition prior to burial and the establishment of anoxic conditions. Anaerobic consortia within landfills mediate the processes of polymer hydrolysis, fermentation to organic acids, and mineralization by methanogenesis (Senior \& Balba, 1990). Methanogenesis, the final step of decomposition of refuse in landfills, has received con-

* Author for correspondence. Present address: Office of Naval Research, Code 1141, 800 N. Quincy St, Arlington, VA 22217-5660, USA. Tel. (703) 696 2660; fax (703) 6961212. siderable attention (Barlaz et al., 1987; Archer \& Peck, 1989) driven in part by interest in methane as an alternative fuel source (Campbell et al., 1985). For high molecular mass polymeric materials in MSW, however, polymer breakdown to monomers and their subsequent fermentation to organic acids must occur prior to methanogenesis.

Laboratory scale landfills or lysimeters have been widely used to study the degradation of refuse by anaerobic microbial consortia (Bookter \& Ham, 1982; Barlaz et al., 1989a, b; Pohland et al., 1985). These laboratory models have proven useful for hypothesis testing about landfill processes, however, extrapolation of models to full-scale facilities can be limited, because of diversity among and heterogeneity within landfills (Parkes \& Senior, 1988). To date, microbiological data from full-scale, operating landfills are few (Campbell et al., 1985) owing to the logistical difficulties inherent in their excavation.

The purpose of this study was (i) to culture and enumerate populations of fermentative anaerobic and aerobic bacteria; and (ii) to estimate populations of polymer-degrading micro-organisms in refuse excavated from three MSW landfills.

\section{Methods}

Study sites. Fresh Kills Landfill in Staten Island, New York was excavated 6-10 October, 1989 (Suflita et al., 1992); the area typically receives about $109 \mathrm{~cm}$ of rain and $63 \mathrm{~cm}$ of snow annually. Upper 
layers of refuse were relatively dry, however, refuse collected from below the water table was saturated, creating a dark grey slime. Los Reales Landfill in Tucson, AZ was excavated on 21 November, 1989; Tucson receives an average of $28 \mathrm{~cm}$ of rain per year. The Naples Landfill in Naples, FL, which receives about $135 \mathrm{~cm}$ of rain annually, was excavated on 12-14 March, 1990. All landfill excavations were conducted in collaboration with The Garbage Project, University of Arizona.

Sample collection. Refuse samples from Fresh Kills and Naples Landfill were collected with a bucket auger (Kellett's Well Boring, Simpsonville, SC). Refuse samples from the Los Reales Landfill were collected with a back hoe. All samples were collected from depths $>3 \mathrm{~m}$ to avoid contamination with surface refuse. Samples were dated from newspapers found in the excavated refuse. Prior to microbiological analysis, refuse samples were passed through a $5 \mathrm{~cm}$ mesh screen to remove larger debris. Exposure of samples to air was minimized as much as possible during sample collection.

Immediately upon collection, refuse samples from each site (Fresh Kills Landfill, 5 samples; Los Reales Landfill, 2 samples; Naples Landfill, 5 samples) were placed in sterile Petri dishes, then enclosed in anaerobic bags (GasPak, BBL, Becton Dickinson) with an atmosphere of $5-10 \%(\mathrm{v} / \mathrm{v}) \mathrm{CO}_{2}$. The anaerobic bags were kept cold on blue ice during transport to the Environmental Safety Department where they were placed in an anaerobic chamber (Forma Scientific Model 1024, Marietta, $\mathrm{OH}$ ) with an atmosphere of $85 \% \mathrm{~N}_{2}, 10 \% \mathrm{H}_{2}$, and $5 \% \mathrm{CO}_{2}$, by vol.

Sample preparation. Inside an anaerobic chamber, $10 \mathrm{~g}$ of refuse was removed from the centre of each sample and added to a stomacher bag (Tekmar, Cincinnati, $\mathrm{OH}$ ) containing $300 \mathrm{ml}$ of pre-reduced, anaerobically sterilized (PRAS) buffer (Scott Laboratories) and mixed for approximately $1 \mathrm{~min}$. This extract was serially diluted in PRAS buffer prior to inoculation.

Viable counts of fermentative and hydrolytic anaerobes. To culture fermentative bacteria, $0 \cdot 1 \mathrm{ml}$ diluted extract was inoculated under a continuous stream of $\mathrm{N}_{2}$ into each medium using a VPI Anaerobic Culture System (Bellco). Roll tubes were prepared immediately upon inoculation on a Bellco tube spinner. Parallel sets of roll tube cultures were incubated at $22^{\circ} \mathrm{C}$ and $37^{\circ} \mathrm{C}$ for approximately $1-2$ weeks or until the number of c.f.u. remained unchanged. C.f.u. were normalized per gram dry weight of refuse samples.

Fermentative anaerobes were isolated on Medium 10 (Carr Scarborough), which is a non-selective, enriched medium for isolation and enumeration of carbohydrate-fermenting bacteria (Caldwell \& Bryant, 1966). Briefly, 11 of Medium 10 contained: glucose, $0.05 \mathrm{~g}$; cellobiose, $0.05 \mathrm{~g}$; soluble starch, $0.05 \mathrm{~g}$; yeast extract, $0.05 \mathrm{~g}$; trypticase, $0.2 \mathrm{~g}$; haemin; mineral salts; a mixture of volatile fatty acids (acetic acid, propionic acid, $n$-butyric acid, $n$-valeric acid, isovaleric acid, isobutyric acid, DL- $\alpha$-methylbutyric acid), resazurin, and cysteine sulphide.

Polymer-degrading anaerobes from Fresh Kills and Tucson Landfills were cultured on peptone yeast glucose (PYG) agar amended with the polymer of interest. Differential staining or clearing of the medium identified polymer-degrading microbes. Anaerobic starch-degrading bacteria were identified by adding approximately $0.5 \mathrm{ml}$ saturated KI solution to colonies growing on PYG medium with $0.2 \%$ soluble starch. Starch hydrolysis was indicated by clear zones around colonies. Proteolytic degraders were determined by adding several drops of $0.05 \%$ naphthol blue black (amido black, Sigma) in $7 \%(\mathrm{v} / \mathrm{v})$ acetic acid solution to colonies growing on PYG agar amended with $0.4 \%$ gelatin. Colonies producing extracellular proteases were surrounded by clear zones. To isolate cellulolytic bacteria, ball-milled cellulose was added (Gerhardt et al., 1981) to either PYG medium or to minimal medium (L-salts medium, Leadbetter \& Foster, 1960). Minimal medium was used to avoid potential catabolite repression of cellulase activity by glucose in PYG medium (Khan \& Patel, 1990). Roll tubes were examined for clearing of the cellulose.

Viable counts of aerobic bacteria. Aerobic bacteria were estimated by serial dilution in phosphate buffer $\left(0.0175 \mathrm{M}-\mathrm{Na}_{2} \mathrm{HPO}_{4} ; 0.033 \mathrm{M}\right.$ $\mathrm{KH}_{2} \mathrm{PO}_{4} ; \mathrm{pH} 6.8$ ) and culturing with pour plates of Standard Methods Agar (Difco). Parallel sets of cultures were incubated at $22{ }^{\circ} \mathrm{C}$ and $37^{\circ} \mathrm{C}$.

Direct microscopic counts of bacterial numbers. Between 0.5 and $1.0 \mathrm{~g}$ refuse were fixed in a final concentration of $3.7 \%(w / v)$ formaldehyde. Samples for direct microscopic counts of acridine orange-stained cells were prepared using a modification of the methods of Ellery \& Schleyer (1984) and Velgji \& Albright (1986). Briefly, all samples were brought up to a known volume with filtered $(0.2 \mu \mathrm{m}) 10 \%(\mathrm{w} / \mathrm{v})$ sodium pyrophosphate and incubated for 5-10 min. The samples were cooled to $0^{\circ} \mathrm{C}$ and alternately sonicated and cooled ( $30 \mathrm{~s}$ each) for $3 \mathrm{~min}$. These samples were then stained with acridine orange and filtered on to $0.2 \mu \mathrm{m}$ porosity Nuclepore filters; the bacteria were counted as described by Hobbie et al. (1977), and bacterial numbers were normalized to dry weight of refuse.

\section{Results}

Refuse samples used for culturing bacteria from Fresh Kills Landfill dated from 1962/1965 (the sample contained a mixture of refuse from two years) to 1988 (Table 1). Moisture levels for these samples ranged from $23.4 \%$ in the 1980 sample to $74.7 \%$ in the 1971 sample. In situ temperatures were lowest for older refuse samples, ranging from $18 \cdot 3^{\circ}(1962 / 1965)$ to $43 \cdot 3^{\circ} \mathrm{C}(1988)$ at five Fresh Kills Landfill sites sampled for culturing bacteria. All Fresh Kills Landfill sites were characterized by relatively high densities of bacteria, as determined by direct microscopic counts $\left(1 \cdot 1-5 \cdot 8 \times 10^{10}\right.$ bacteria (g dry $\mathrm{wt})^{-1}$ using acridine orange stain. Despite predominantly anaerobic conditions in the landfill, aerobic bacteria were culturable at numbers comparable to anaerobes. Anaerobic bacteria ranged from $0 \cdot 2-32 \cdot 8 \times 10^{6}$ c.f.u. (g dry wt $)^{-1}$ at $22^{\circ} \mathrm{C}$ and $0.5-842 \times 10^{6}$ c.f.u. (g dry wt) ${ }^{-1}$ at $37^{\circ} \mathrm{C}$; aerobic bacteria ranged from $0.5-23.2 \times 10^{6}$ c.f.u. (g dry wt) $)^{-1}$ at $22^{\circ} \mathrm{C}$ and $0.2-17 \cdot 4 \times 10^{6}$ c.f.u. (g dry wt) ${ }^{-1}$ at $37^{\circ} \mathrm{C}$. The lowest numbers of anaerobic and aerobic bacteria were found in the oldest refuse (1962/1965). A positive correlation was found between total numbers of anaerobic bacteria cultured at $37^{\circ} \mathrm{C}$ and percent moisture $(r=0.92 ; P<0.03$; Systat). No significant correlation, however, was found between moisture and anaerobes cultured at $22^{\circ} \mathrm{C}$, or moisture and aerobes cultured at $22^{\circ}$ or $37^{\circ} \mathrm{C}$.

Refuse collected from Los Reales and Naples Landfills dated from the 1980s. Two refuse samples excavated from Los Reales Landfill were characterized by lower moisture than Fresh Kills Landfill; in situ temperature data were not collected from Los Reales Landfill. Despite lower moisture, direct microscopic counts for Los Reales Landfill $\left(2 \cdot 82-4.17 \times 10^{10}\right.$ bacteria $(\mathrm{g} \text { dry } \mathrm{wt})^{-1}$ were similar in magnitude for counts from Fresh Kills Landfill, 
Table 1. Enumeration of bacteria from three landfills by direct microscopic counts and by culturing on solid media at $22^{\circ} \mathrm{C}$ and $37^{\circ} \mathrm{C}$

\begin{tabular}{|c|c|c|c|c|c|c|c|c|c|}
\hline \multirow[b]{2}{*}{ Landfill } & \multirow[b]{2}{*}{ Site } & \multirow[b]{2}{*}{ Year } & \multirow{2}{*}{$\begin{array}{l}\text { Water } \\
(\%)\end{array}$} & \multirow{2}{*}{$\begin{array}{c}\text { Site } \\
\text { temperature } \\
\left({ }^{\circ} \mathrm{C}\right)\end{array}$} & \multirow{2}{*}{$\begin{array}{c}\text { AODC } \\
{\left[10^{-10} \times\right.} \\
\text { bacteria } \\
\left.(\mathrm{g} \text { dry } w t)^{-1}\right]\end{array}$} & \multicolumn{2}{|c|}{$\begin{array}{l}\text { Anaerobes } \\
{\left[10^{-6} \times \text { c.f.u. }(\mathrm{g} \text { dry wt) })^{-1}\right]^{*}}\end{array}$} & \multicolumn{2}{|c|}{$\begin{array}{c}\text { Aerobes } \\
{\left[10^{-6} \times \text { c.f.u. }(\mathrm{g} \mathrm{dry} \mathrm{wt})^{-1}\right]^{*}}\end{array}$} \\
\hline & & & & & & $22^{\circ} \mathrm{C}$ & $37^{\circ} \mathrm{C}$ & $22^{\circ} \mathrm{C}$ & $37^{\circ} \mathrm{C}$ \\
\hline Fresh Kills & $8-2$ & 1988 & $40 \cdot 1$ & $43 \cdot 3$ & $4 \cdot 6 \pm 3 \cdot 0^{*}$ & $20.5 \pm 1.8$ & $23 \cdot 0 \pm 3.5$ & $9 \cdot 68 \pm 0.15$ & $8 \cdot 1 \pm 0.5$ \\
\hline Fresh Kills & $1-2$ & 1984 & 28.9 & $29 \cdot 4$ & $1 \cdot 10 \pm 0 \cdot 10^{*}$ & $1 \cdot 5 \pm 0$ & $2.91 \pm 0.52$ & $7.02 \pm 0.74$ & $4 \cdot 44 \pm 0 \cdot 14$ \\
\hline Fresh Kills & $3-2$ & 1980 & $23 \cdot 4$ & $21 \cdot 6$ & $5.8 \pm 0.9 *$ & $0.65 \pm 0.06 \dagger$ & $2.79 \pm 0.22 \dagger$ & $11.5 \pm 0.4 \dagger$ & $7.04 \pm 1.21 \dagger$ \\
\hline Fresh Kills & $9-2$ & 1971 & 74.7 & $21 \cdot 6$ & $5 \cdot 1 \pm 2 \cdot 7^{*}$ & $32.8 \pm 1.5 \dagger$ & $842 \pm 54 \dagger$ & $23.2 \pm 0.6 \dagger$ & $17.4 \pm 0.4 \dagger$ \\
\hline Fresh Kills & $5-3$ & $1962 / 65$ & $43 \cdot 3$ & $18 \cdot 3$ & $2.4 \pm 0.9 *$ & $0.2 \pm 0.3$ & $0.543 \pm 0.011$ & $0.490 \pm 0.301$ & $0.217 \pm 0.005$ \\
\hline Los Reales & 1 & 1986 & $26 \cdot 2$ & ND & $2 \cdot 82$ & $3.1 \pm 0.4 \dagger$ & $0.725 \pm 0.015 \dagger$ & $0.354 \pm 0.015 \dagger$ & $0.0154 \pm 0.0070 \dagger$ \\
\hline Los Reales & 2 & 1986 & $6 \cdot 1$ & ND & $4 \cdot 17$ & $0.229 \pm 0.038 \dagger$ & $2.86 \pm 0.13 \dagger$ & $1.88 \pm 0.06 \dagger$ & $1.50 \pm 0.06 \dagger$ \\
\hline Naples & $1-2$ & 1987 & $16 \cdot 1$ & $49 \cdot 4$ & $4 \cdot 88$ & ND & $50 \cdot 3 \pm 0.9$ & ND & $50 \cdot 8 \pm 0 \cdot 5$ \\
\hline Naples & $2-4$ & 1987 & $35 \cdot 4$ & $57 \cdot 2$ & $2 \cdot 81$ & ND & $0.0789 \pm 0.0080$ & ND & $0.020 \pm 0.008$ \\
\hline Naples & $2-6$ & 1987 & $22 \cdot 0$ & $60 \cdot 0$ & 3.00 & ND & $0.632 \pm 0.002$ & ND & $0.683 \pm 0.007$ \\
\hline Naples & $1-3$ & 1987 & $12 \cdot 3$ & $62 \cdot 8$ & 3.05 & ND & $0.26 \pm 0.01$ & ND & $0.486 \pm 0.008$ \\
\hline Naples & $2-8$ & 1982 & 29.5 & 54.4 & 4.05 & ND & $4 \cdot 70 \pm 0.38$ & ND & $9 \cdot 15 \pm 0 \cdot 15$ \\
\hline
\end{tabular}

* Means \pm SD of 3 subsamples.

$\dagger$ Significant difference between two temperatures at $P \leqslant 0.05$.

$\ddagger$ Dated year of sample.

$\S$ AODC, acridine orange direct count.

ND, no data.

Table 2. Fermentative bacteria degrading protein or starch in refuse excavated from Fresh Kills and Los Reales landfills

Figures are mean percentages $\pm \mathrm{SD}$ from 3 replicates. Absolute figures $\left[10^{-6} \times\right.$ c.f.u. $\left.(\mathrm{g} \text { dry wt })^{-1}\right]$ representing $100 \%$ are in parentheses.

\begin{tabular}{|c|c|c|c|c|c|c|}
\hline \multirow[b]{2}{*}{ Landfill } & \multirow[b]{2}{*}{ Site } & \multirow[b]{2}{*}{ Year* } & \multicolumn{2}{|c|}{ Proteolytic bacteria } & \multicolumn{2}{|c|}{ Amylolytic bacteria } \\
\hline & & & $22^{\circ} \mathrm{C}$ & $37^{\circ} \mathrm{C}$ & $22^{\circ} \mathrm{C}$ & $37^{\circ} \mathrm{C}$ \\
\hline Fresh kills & $8-2$ & 1988 & $\begin{array}{c}15 \pm 4 \\
(53 \cdot 3 \pm 1 \cdot 6)\end{array}$ & $\begin{array}{c}0.5 \pm 0.8 \\
(43.6 \pm 11.0)\end{array}$ & $\begin{array}{c}12 \pm 7 \\
(4 \cdot 01 \pm 0 \cdot 50)\end{array}$ & $\begin{array}{c}2 \pm 2 \\
(8.94 \pm 0.39)\end{array}$ \\
\hline Fresh kills & $1-2$ & 1984 & $\begin{array}{c}11 \pm 4 \\
(22 \cdot 1 \pm 1 \cdot 8)\end{array}$ & $\begin{array}{c}4 \pm 2 \\
(2.97 \pm 0.27)\end{array}$ & $\begin{array}{c}4.0 \pm 0.5 \\
(1.63 \pm 1 \cdot 16)\end{array}$ & $\begin{array}{c}2 \pm 9 \\
(2 \cdot 69 \pm 0 \cdot 15)\end{array}$ \\
\hline Fresh kills & $3-2$ & 1980 & $\begin{array}{c}2 \cdot 0 \pm 0.5 \\
(7.91 \pm 0.47)\end{array}$ & $\begin{array}{c}2 \cdot 0 \pm 0 \cdot 1 \\
(7 \cdot 32 \pm 0 \cdot 18)\end{array}$ & $\begin{array}{c}3.0 \pm 0.4 \\
(3.36 \pm 1.55)\end{array}$ & $\begin{array}{c}2.0 \pm 0.5 \\
(6.54 \pm 0.55)\end{array}$ \\
\hline Fresh kills & $9-2$ & 1971 & $\begin{array}{c}10 \pm 3 \\
(25 \cdot 2 \pm 0 \cdot 8)\end{array}$ & $\begin{array}{c}0.9 \pm 0.3 \\
(14 \cdot 1 \pm 0.4)\end{array}$ & $\begin{array}{c}0.2 \pm 0.3 \\
(708 \pm 176)\end{array}$ & $\begin{array}{c}2 \pm 2 \\
(230 \pm 5)\end{array}$ \\
\hline Fresh kills & $5-3$ & 1965 & $\begin{array}{c}7 \pm 2 \\
(0.35 \pm 0.04)\end{array}$ & $\begin{array}{c}0 \pm 0 \\
(0.90 \pm 0.02)\end{array}$ & $\begin{array}{c}0.4 \pm 0.4 \\
(1.30 \pm 0.03)\end{array}$ & $\begin{array}{c}4 \pm 1 \\
(3.88 \pm 0.09)\end{array}$ \\
\hline Los Reales & 1 & 1986 & $\begin{array}{c}0.6 \pm 0.3 \\
(0.84 \pm 0.02)\end{array}$ & $\begin{array}{c}0.2 \pm 0.4 \\
(6.88 \pm 0.08)\end{array}$ & $\begin{array}{c}0.2 \pm 0.4 \\
(0.67 \pm 0.07)\end{array}$ & $\begin{array}{c}0.7 \pm 0.8 \\
(8 \cdot 40 \pm 0.42)\end{array}$ \\
\hline Los Reales & 2 & 1986 & $\begin{array}{c}5.5 \pm 1.2 \\
(2.87 \pm 0.07)\end{array}$ & $\begin{array}{c}3.4 \pm 1.2 \\
(3.43 \pm 0.08)\end{array}$ & $\begin{array}{c}13 \cdot 8 \pm 7 \cdot 2 \\
(2 \cdot 57 \pm 0.35)\end{array}$ & $\begin{array}{c}5.3 \pm 1 \cdot 0 \\
(3.99 \pm 0.26)\end{array}$ \\
\hline
\end{tabular}

* Dated year of sample.

and numbers of culturable fermentative bacteria were within the range found for samples from Fresh Kills Landfill.

The Naples Landfill was characterized by moderate moisture (12.3-35.4\%) and higher temperatures (49.4 $62 \cdot 8^{\circ} \mathrm{C}$ ). Refuse samples from Naples Landfill were only cultured at $37^{\circ} \mathrm{C}$ because of the higher in situ tempera- tures. Both direct microscopic counts and c.f.u. per g dry wt of refuse were, in general, within the range found for refuse from Fresh Kills Landfill.

Bacteria from refuse samples were cultured anaerobically on media enriched with specific polymers to screen for hydrolytic activity (Table 2). Proteolytic colonies represented 0.6 to $15 \%$ and 0 to $4 \%$ of the 
fermentative populations in refuse samples from Fresh Kills and Los Reales Landfills incubated at $22^{\circ} \mathrm{C}$ and $37^{\circ} \mathrm{C}$, respectively. Amylolytic bacteria comprised $0.2-14 \%$ and $0.7-5.3 \%$ of the fermentative population cultured from refuse samples incubated at $22^{\circ} \mathrm{C}$ and $37^{\circ} \mathrm{C}$, respectively. No consistent trend in the percentage of hydrolytic bacteria was evident with age of refuse. Cellulolytic organisms, which were to be identified by clearing of ball-milled cellulose in an agar matrix, were not cultured from samples from Fresh Kills, Los Reales or Naples Landfills.

\section{Discussion}

Although relatively high numbers of fermentative bacteria $\left[10^{5}-10^{8}\right.$ c.f.u. (g dry wt) $\left.{ }^{-1}\right]$ were cultured from landfilled refuse, only a small percentage $(0-15 \%)$ were capable of producing extracellular hydrolytic enzymes for starch or protein degradation. While hydrolysis is a prerequisite for utilization of complex biopolymers by micro-organisms, initial enzymic attack may depend on a select few organisms (Colberg, 1988). Enumeration of c.f.u. on solid media is undoubtedly a very conservative estimate of the total number of fermentative bacteria in a landfill, since only some bacteria will be culturable on the medium provided. Moreover, the isolation of a viable organism from a landfill does not imply that the organism is active in situ; it may be merely surviving under landfill conditions. By contrast, the direct microscopic counts of acridine orange stained bacteria $\left[10^{10}\right.$ bacteria ( $\mathrm{g}$ dry $\mathrm{wt})^{-1}$ ] may be an overestimate of viable bacteria, because non-viable cells may be inadvertently counted by this method.

Microbiological data from full-scale landfills is very limited, and many earlier studies focused on aerobic rather than anaerobic populations (Cook et al., 1967). This emphasis on aerobic populations is somewhat surprising, since aerobic micro-organisms undoubtedly play only a minor role in refuse decomposition and gas production in landfills. In the present study, approximately $10^{4}$ to $10^{7}$ aerobic bacteria (g dry wt) ${ }^{-1}$ were cultured from landfilled refuse samples on solid media. Campbell et al. (1985) suggested that aerobes may contribute to heat production prior to the development of anoxic conditions in buried refuse. Cook et al. (1967) isolated aerobic fungi, streptomycetes, and photosynthetic bacteria from a sanitary landfill, fresh household refuse, and seepage from the landfill. Public health considerations were the impetus for several studies of landfill microbiology which focused on the isolation of indicator organisms such as coliforms and faecal streptococci from model and full scale landfills which received both municipal and hospital waste (Donnelly \& Scarpino, 1984; Pahren, 1987). MSW that had been incubated for 20 months in a model landfill contained an estimated $10^{5}$ to $10^{6}$ fungi and $10^{6}$ actinomycetes by plate counts, and $10^{6}$ to $10^{8}$ aerobic proteolytic bacteria ( $\mathrm{g}$ dry wt) ${ }^{-1}$ by MPN counts using liquid media (Filip \& Kuster, 1979).

Our screening of colonies for polymer hydrolysis suggested that only a small proportion $(<15 \%)$ of the fermentative population produced extracellular enzymes capable of hydrolyzing protein and starch. Jones et al. (1983) examined hydrolytic bacteria in refuse from Aveley Landfill, Essex, Great Britain, as a function of depth. Proteolytic and amylolytic bacteria were each approximately $1 \%$ of the total anaerobic population. In a separate lysimeter study, Jones \& Grainger (1983) used MPN counts to estimate changes in bacterial numbers during a $120 \mathrm{~d}$ laboratory incubation of water-saturated, freshly pulverized domestic refuse. Proteolytic organisms decreased from approximately $10^{8}$ to $10^{6}$ organisms ( $\mathrm{g}$ dry $w t)^{-1}$ during the course of the incubation while amylolytic organisms were approximately $10^{6}$ (g dry wt) $)^{-1}$.

To date, very few cellulolytic bacteria from landfills have been isolated and characterized (Bagnara et al., 1985; Westlake, 1989). Our inability to isolate cellulolytic bacteria may be the result of (i) their low abundance in landfills (Jones et al. 1983); (ii) difficulty in extracting bacteria from refuse; (iii) inadequacy of cellulase detection (Robson \& Chambliss, 1989); or most likely, (iv) their inability to grow on the solid media provided. Since $<1 \%$ of the total bacteria determined by microscopic counts were culturable, cellulose-degrading bacteria may have easily been missed.

Logistic constraints resulted in analysis of relatively few refuse samples from the very heterogeneous landfill environment. Clearly, it is not appropriate to generalize from three sites to the approximately 7000 landfills in the United States which vary considerably in mode and efficiency of operation. However, we believe that our data on landfill microbiology will provide a baseline for future studies on a relatively poorly understood community of decomposers. An understanding of the establishment and maintenance of anaerobic communities in landfills is critical to improving leachate quality and thereby reducing the risk of environmental impacts of landfills such as groundwater contamination (Stegmann, 1983; Harper \& Pohland, 1988).

Dr W. L. Rathje and The Garbage Project, Dr C. P. Gerba, Dr R. K. Ham, Dr J. S. Robinson, Dr J. M. Suflita, Mr W. Hughes, Mr L. W. King, and Mr B. Kellet collaborated on the Fresh Kills Landfill excavation. Moisture data were supplied by Dr J. M. Suflita. The research program was funded in its entirety by contributions from the Council for Solid Waste Solutions, E. I. Dupont de Nemours \& Co., Exxon Chemical Co., Hercules, Inc., Hoechst Celanese, Jefferson Smurfitt/Container Corporation of America, National Council of the Paper Industry on Air and Stream Improvement, The Perseco Co., The Procter \& Gamble Co., Scott Paper Co., and Sonoco Products Co. The 
authors thank Dr T. W. Federle and Ms B. A. Nuck for helpful discussions.

\section{References}

Archer, D. B. \& PeCK, M. W. (1989). The microbiology of methane production in landfills. In Microbiology of Extreme Environments and its Potential for Biotechnology, pp. 187-204. Edited by M. S. da Costa, J. C. Duarte \& R. A. D. Williams. London \& New York: Elsevier Applied Science.

ARCHER, D. B. \& Robertson, J. A. (1986). The fundamentals of landfill microbiology. In Energy from Landfill Gas, pp. 116-122. Edited by J. R. Emberton \& R. F. Emberton. Oxfordshire: Harwell Laboratory.

Bagnara, C., Toci, R., Gaudin, C. \& Belaich, J. P. (1985). Isolation and characterization of a cellulolytic micro-organism Cellulomonas fermentans sp. nov. International Journal for Systematic Bacteriology 35, 502-507.

BarlaZ, M. A., MiLKe, M. W. \& HaM, R. K. (1987). Gas production parameters in sanitary landfill simulators. Waste Management and Research 5, 27-39.

Barlaz, M. A., HAM, R. K. \& Schaefer, D. M. (1989a). Massbalance analysis of anaerobically decomposed refuse. Journal of Environmental Engineering 115, 1088-1102.

Barlaz, M. A., D. M. Schaefer \& HAM, R. K. (1989 b). Bacterial population development and chemical characteristics of refuse decomposition in a simulated sanitary landfill. Applied and Environmental Microbiology 55, 55-65.

BOOKTER, T. J. \& HAM, R. K. (1982). Stabilization of solid waste in landfills. Journal of Environmental Engineering Division, Proceedings of the American Society of Civil Engineers 108, 1089-1100.

Caldwell, D. R. \& Bryant, M. P. (1966). Medium without rumen fluid for nonselective enumeration and isolation of rumen bacteria. Applied Microbiology 14, 794-801.

Campbell, D. J. V., Fielding, E. R., \& ARCheR, D. B. (1985). Understanding refuse decomposition practices to improve landfill gas energy potential. In Proceedings of Energy from Biomass, Third EC Conference, pp. 1151-1155. Edited by W. Palz. London: Elsevier Science Publishing.

CARRA, J. S. \& Cossu, R. (1990). International Perspectives on Municipal Solid Wastes and Sanitary Landfilling. San Diego: Academic Press.

Colberg, P. J. (1988). Anaerobic microbial degradation of cellulose, lignin, oligolignols, and monoaromatic lignin derivatives. In Biology of Anaerobic Microorganisms, pp. 333-372. Edited by A. J. B. Zehnder. New York: John Wiley and Sons.

Cook, H. A., Cromwell, D. L. \& Wilson, H. A. (1967). Microorganisms in household refuse and seepage water from sanitary landfills. Proceedings of the West Virginia Academy of Sciences 39, 107-114.

DonNelly, J. A. \& SCARPINo, P. V. (1984). Isolation, characterization, and identification of micro-organisms from laboratory and full-scale landfills. EPA Project Summary, EPA600/S2-84-119, pp. 1-7. Cincinnati: Municipal Environmental Research Laboratory.

ElleRY, W. N. \& SCHLeYer, M. H. (1984). Comparison of homogenization and ultrasonication as techniques in extracting attached sedimentary bacteria. Marine Ecology - Progress Series 15, 247-250.

FILIP, Z. \& KUSTER, E. (1979). Microbial activity and the turnover of organic matter in a municipal refuse disposed of in an landfill. European Journal of Applied Microbiology \& Biotechnology 7, 371-379.

Gerhardt, P., Murray, R. G. E., Costilow, R. N., Nester, E. W., WoOd, W. A., Krieg, N. R. \& PhIllips, G. B. (1981). Manual of
Methods for General Bacteriology. Washington, DC: American Society for Microbiology.

Grainger, J. M., Jones, K. L. \& HotTen, P. M. (1984). Estimation and control of microbial activity in landfill. In Microbiological Methods for Environmental Biotechnology, pp. 259-273. Edited by J. M. Grainger \& J. M. Lynch. Orlando: Academic Press.

HARPER, S. R. \& Pohland, F. G. (1988). Design and management stategies for minimizing environmental impact at municipal solid waste landfill sites. Proceedings of Joint American Society of Civil Engineers-Canadian Society of Civil Engineers National Conference on Environmental Engineering, Vancouver, pp. 669-688.

HobBiE, J. E., DALEY, R. J. \& JASPER, S. (1977). Use of Nuclepore filters for counting fluorescence microscopy. Applied and Environmental Microbiology 33, 1225-1228.

JoNEs, K. L. \& GRAINGER, J. M. (1983). The application of enzyme activity measurements to a study of factors affecting protein, starch and cellulose fermentation in domestic refuse. European Journal of Applied Microbiology and Biotechnology 18, 181-185.

Jones, K. L., ReEs, J. F. \& Grainger, J. M. (1983). Methane generation and microbial activity in a domestic refuse landfill site. European Journal of Applied Microbiology \& Biotechnology 18, 242-245.

Khan, A. W. \& Patel, G. B. (1990). Cellulose degradation by mesophilic anaerobic bacteria. In Synthesis and Biodegradation of Cellulose, pp. 355-375. Edited by C. D. Haigler \& P. J. Weimer. New York \& Basel: Marcel Dekker.

LEADBETTER, L. R. \& FosteR, J. W. (1960). Bacterial oxidation of gaseous alkanes. Archives of Microbiology 35, 92-104.

PAHREN, H. R. (1987). Microorganisms in municipal solid waste and public health implications. CRC Critical Reviews in Environmental Control. 17, 187-228.

Parkes, R. J. \& Senior, E (1988). Multistage chemostats and other models for studying anoxic ecosystems. In Handbook of Laboratory Model Systems for Microbial Ecosystems, vol. 1., pp. 51-71. Edited by J. W. T. Wimpenny. Boca Raton: CRC Press.

Pohland, F. G., Harper, S. R., Chang, K-C, Dertien, J. T. \& Chian, E. S. K. (1985). Leachate generation and control at landfill disposal sites. Water Pollution Research Journal of Canada 20, 10-24.

Robson, L. M. \& Chambliss, G. H. (1989). Cellulases of bacterial origin. Enzyme and Microbial Technology 11, 626-644.

SENIOR, E. \& Balba, M. T. M. (1990). Refuse decomposition. In Microbiology of Landfill Sites, pp. 18-57. Edited by E. Senior. Boca Raton: CRC Press.

Sleat, R., Harries, C., Viney, I. \& Rees, J. F. (1987). Activities and distribution of key microbial groups in landfill. Proceedings of the ISWA Symposium on Process, Technology and Environmental Impact of Sanitary Landfills, Cagliari, Sardinia, pp. 1-14.

StEGMANN, R. (1983). New aspects on enhancing biological processes in sanitary landfill. Waste Management and Research 1, 201-211.

Suflita, J. M., Gerba, C. P., Ham, R. K., Palmisano, A. C., Rathje, W. L. \& Robinson, J. A. (1992). Microbiological, chemical, and archaeological investigation of the Fresh Kills Landfill. Environmental Science and Technology, 26, 1486-1494.

United States Environmental Protection Agency (1990). Characterization of Municipal Solid Waste in the United States: 1990 Update. EPA Report no. 530-SW-90-042. US Department of Commerce, National Technical Information Service.

VelgYi, M. I. \& Albright, L. J. (1986). Microscopic enumeration of attached marine bacteria of seawater, marine sediment, fecal matter, and kelp blade samples following pyrophosphate and ultrasound treatments. Canadian Journal of Microbiology 32, 121-126.

WeStLAKe, K. (1989). Cellulolytic bacteria in sanitary landfill. In Proceedings in Landfill Microbiology Research and Development Workshop, pp. 20-33. Edited by P. S. Lawson \& Y. R. Alston, Oxfordshire: Harwell Laboratory. 